\title{
MENINGKATKAN KEMAMPUAN SIKAP ILMIAH ANAK MELALUI PEMBELAJARAN SAINS DENGAN METODE INKUIRI
}

\author{
Winny Nuraeni, Ali Nugraha, Nur Faizah Romadona \\ Universitas Pendidikan Indonesia, Jln. Setiabudhi no. 229 Bandung \\ e-mail:win.nuraeni@gmail.com
}

\begin{abstract}
Improving Children's Scientific Attitude Through Science Teaching Learning with Inquiry Method. This research was prompted by the problem found among B1 Group children of RA Ar-Royyan, namely low scientific attitude. The follow-up to this problem is improvement in teaching and learning; in this regard, the researcher designed science teaching and learning with inquiry method. The purpose of this research is to find about improvement in B1 group children's scientific attitude after the implementation of science teaching and learning with inquiry method. The subjects consisted of 8 (eight) B1 group children of RA Ar-Royyan Dungus Cariang District, Bandung, with 5 male and 3 female students, respectively. The research adopted classroom action research method. The techniques of data collection employed were observation, interview, and documentation. The findings show that in the pre-cycle, $75 \%$ of the children were under the category of undeveloped, $12.5 \%$ starting to develop, $12.5 \%$ developing according to expectation, and $0 \%$ developing very well. At the end of cycle $1,12.5 \%$ of the children were under the category of undeveloped, $25 \%$ starting to develop, $50 \%$ developing according to expectation, and $12.5 \%$ developing very well. At the end of cycle II, children's scientific attitude was at the category of undeveloped for $0 \%$, starting to develop $0 \%$, developing according to expectation $75 \%$, and developing very well $25 \%$. In conclusion, science teaching and learning with inquiry method can improve the scientific attitude of B1 group children of RA Ar-Royyan Dungus Cariang District, Bandung. It is recommended that teachers and principal of the school under research make science teaching and learning with inquiry method an alternative in teaching and learning to improve children's scientific attitude.
\end{abstract}

Keywords : scientific attitude, science teaching and learning, inquiry method.

\begin{abstract}
Abstrak : Meningkatkan Kemampuan Sikap Ilmiah Anak Melalui Pembelajaran Sains dengan Metode Inkuiri. Penelitian ini dilakukan atas dasar permasalahan yang muncul pada anak kelompok B1 RA Ar-Royyan, yaitu rendahnya kemampuan sikap ilmiah anak. Tindak lanjut dari permasalahan tersebut adalah perlu adanya perbaikan dalam pembelajaran, dalam hal ini peneliti merancang penelitian melalui pembelajaran sains dengan metode inkuiri. Tujuan dari penelitian ini untuk mengetahui peningkatan kemampuan sikap ilmiah pada anak kelompok B1 setelah penerapan pembelajaran sains dengan metode inkuiri. Subjek pada penelitian adalah anak kelompok B1 RA Ar-Royyan Kecamatan Dungus Cariang Bandung berjumlah 8 anak, yang terdiri dari 5 anak laki-laki dan 3 anak perempuan. Metode penelitian yang digunakan adalah Penelitian Tindakan Kelas (PTK). Teknik pengumpulan data dalam penelitian dilakukan melalui observasi, wawancara, dan dokumentasi. Hasil penelitian yang diperoleh, yaitu pada kondisi pra siklus anak dengan kategori belum berkembang (BB) $75 \%$, mulai berkembang (MB) $12,5 \%$, berkembang sesuai harapan (BSH) $12,5 \%$, dan berkembang sangat baik (BSB) $0 \%$. Pada akhir siklus I, pada kategori belum berkembang (BB) $12,5 \%$, mulai berkembang (MB) $25 \%$, berkembang sesuai harapan (BSH) $50 \%$, dan berkembang sangat baik (BSB) 12,5\%. Pada akhir siklus II, kemampuan sikap ilmiah anak pada kategori belum berkembang (BB) $0 \%$, mulai berkembang (MB) $0 \%$, berkembang sesuai harapan (BSH) $75 \%$, dan berkembang
\end{abstract}


sangat baik (BSB) 25\%. Kesimpulan dari penelitian ini adalah bahwa pembelajaran sains dengan metode inkuiri dapat meningkatkan kemampuan sikap ilmiah pada anak kelompok B1 RA Ar-Royyan Kecamatan Dungus Cariang Bandung. Rekomendasi bagi guru dan sekolah dari penelitian yang telah dilakukan hendaknya pembelajaran sains dengan metode inkuiri ini dapat menjadi alternatif dalam pembelajaran untuk meningkatkan kemampuan sikap ilmiah pada anak.

Kata Kunci : kemampuan sikap ilmiah, pembelajaran sains, metode inkuiri.

Wiyani \& Barnawi (2012, hlm. 78) mengemukakan bahwa secara umum tujuan pendidikan anak usia dini adalah mengembangkan berbagai potensi anak sejak dini sebagai persiapan untuk hidup dan dapat menyesuaikan diri dengan lingkungan. Kebutuhan manusia seiring berkembangnya zaman terus berubah, terutama perkembangan sains, teknologi dan pembangunan. Sehingga apabila anak tidak dibekali life skill (kecakapan hidup) yang memadai, maka anak akan mengalami kesulitan dalam hidupnya. Oleh karena itu, pembelajaran sains penting untuk diberikan sejak dini pada anak, terutama kemampuan sikap ilmiah anak.

Hal yang mendasar ketika anak memiliki sikap ilmiah menurut Leeper (dalam Nugraha, 2008, hlm. 25-32) ialah anak tidak akan tergesa-gesa dalam mengambil keputusan, anak akan dapat melihat segala sesuatu dari berbagai sudut pandang, berhati-hati terhadap informasiinformasi yang diterimanya dan bersifat terbuka. Selain itu sikap ilmiah yang dimiliki anak akan menjadikannya pribadi yang memiliki tingkat kreativitas dan inovasi yang lebih berarti, karena dalam pengembangan pembelajaran sains anak akan melakukan serangkaian proses yang nantinya akan membawa anak pada suatu pengalaman yang penuh warna dan bermakna dengan objek-objek yang ada disekitarnya
Menurut Harlen (dalam Bundu, 2006: 95) sikap ilmiah mengandung dua makna, yaitu attitude toward science dan attitude of science. Attitude toward science mengacu pada sikap terhadap sains dimana lebih menekankan sikap sebagai suatu cara memandang dunia serta berguna bagi pengembangan karir di masa yang akan datang sedangkan sikap attitude of science mengacu pada sikap yang melekat setelah mempelajari sains dimana seperangkat sikap tersebut apabila diikuti akan membantu proses pemecahan masalah.

Sikap ilmiah anak dapat dihasilkan melalui pembinaan, pembiasaan, dan pelatihan. Dengan kata lain, sikap ilmiah ini dapat dimunculkan dan ditingkatkan melalui kegiatan belajar. Harlen (dalam Bundu, 2006, hlm. 27) mengungkapkan bahwa pengembangan sikap ilmiah bukan melalui ceramah melainkan dengan memunculkannya ketika siswa terlibat dalam kegiatan pemecahan masalah. Oleh karena itu, apabila akan memunculkan kemampuan sikap ilmiah anak, diperlukan metode pembelajaran yang tepat dalam mengembangkan kemampuan sikap ilmiah anak.

Metode yang biasa digunakan dalam pembelajaran sains di RA Ar-Royyan adalah metode demonstrasi. Apabila dilihat dari metode pembelajaran yang digunakan, metode ini cukup baik untuk digunakan dalam mengembangkan pembelajaran sains pada anak. Akan tetapi, kegiatan dengan 
metode ini ternyata belum dapat mengoptimalkan seluruh kemampuan sains pada diri anak dalam pengembangan pembelajaran sains, terutama dalam hal mengembangkan sikap-sikap ilmiah. Padahal ruang lingkup pengembangan pembelajaran sains apabila ditinjau dari bidang pengembangan atau kemampuan yang harus dicapai oleh anak menurut Nugraha (2008, hlm. 94) harus mencakup 3 dimensi, yaitu meliputi kemampuan terkait dengan penguasaan produk sains, penguasaan proses sains, dan penguasaan sikap-sikap sains (sikap ilmiah).

Berdasarkan permasalahan tersebut, perlu adanya solusi yang tepat untuk perbaikan dalam meningkatkan kemampuan sikap ilmiah anak kelompok B1 RA ArRoyyan. Moeslichatoen (2004, hlm. 9) mengungkapkan bahwa kunci keberhasilan suatu pembelajaran bukan dari isi dan materi tersebut, tetapi bagaimana metode yang digunakan tepat dan dapat dimaknai oleh anak. Atas dasar tersebut peneliti menawarkan suatu metode pembelajaran sains berupa metode inkuiri.

\section{METODE}

Lokasi pelaksanaan penelitian ini adalah di RA Ar-Royyan yang beralamat di Jln. Rajawali Timur No. 195/76 Gang Arka RT/RW: 04/08, Andir, Bandung. Partisipan dalam penelitian ini adalah anak kelompok B1 RA Ar-Royyan yang berjumlah 8 orang anak, yang terdiri dari 5 anak laki-laki dan 3 anak perempuan.

Metode yang digunakan dalam penelitian ini adalah Penelitian Tindakan Kelas (Classroom Action Research) dengan pendekatan kuantititif.

Model penelitian tindakan kelas yang digunakan yaitu Model Kemmis \& McTaggart. Model ini terdiri dari empat tahapan yaitu perencanaan, pelaksanaan, observasi, dan refleksi yang menjadi sebuah siklus. Jumlah siklus dalam penelitian ini ada dua siklus, dimana setiap siklus terdapat dua tindakan yang diberikan pada anak.

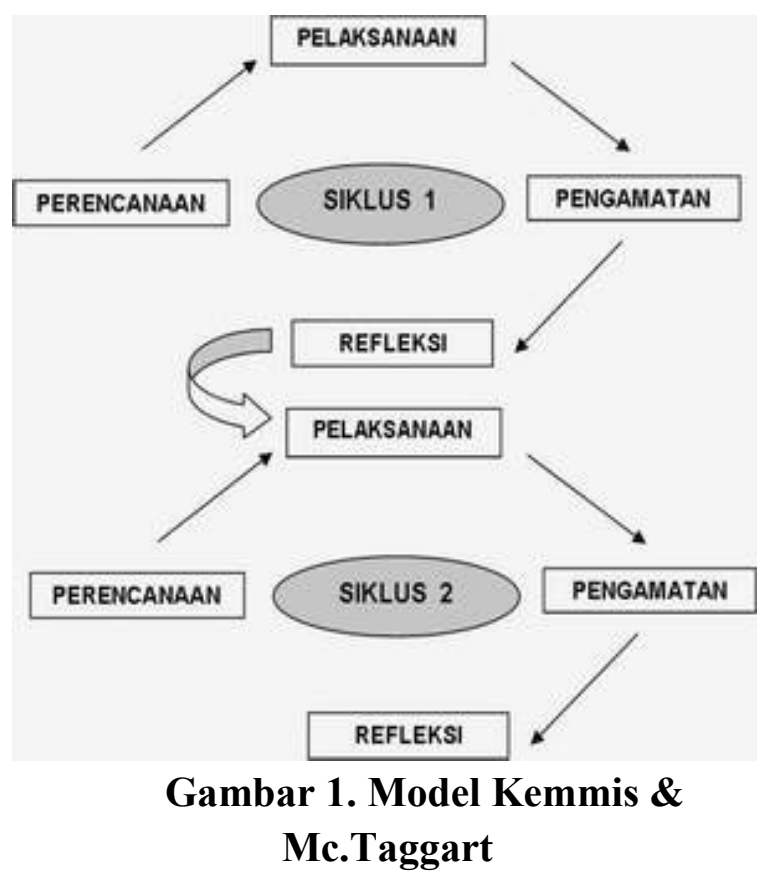

Instrumen yang dikembangkan meliputi instrumen non tes untuk mengetahui perkembangan sikap ilmiah anak. Menurut Arikunto (2010, hlm. 203) instrumen penelitian merupakan alat atau fasilitas yang digunakan oleh peneliti dalam mengumpulkan data agar pekerjaannya lebih mudah dan hasilnya lebih baik, dalam arti lebih cermat, lengkap dan sistematik sehingga lebih mudah diolah. Variasi jenis instrumen penelitian adalah daftar ceklis.

Teknik pengumpulan data dalam penelitian ini dilakukan melalui observasi (pengamatan), wawancara, dan dokumentasi. Penggunaan teknik dan alat pengumpulan data yang tepat memungkinkan diperolehnya data yang objektif.

Teknik analisis data hasil penelitian yang digunakan adalah pendekatan kuantitatif. Untuk memperjelas melihat perubahan kemampuan sikap ilmiah melalui 
pembelajaran sains dengan metode inkuiri anak kelompok B1 RA Ar-Royyan sebelum dan sesudah penelitian, data hasil observasi setiap butir aspek yang diamati selama dua siklus dihitung dengan menggunakan tabel distribusi frekuensi. Menurut Suprapto (2002, hlm. 62) distribusi frekuensi adalah pengelompokkan data ke dalam beberapa kelompok (kelas) dan kemudian dihitung banyaknya data yang masuk ke dalam tiap kelas.

\section{HASIL DAN PEMBAHASAN}

\section{Siklus I}

Hasil dari siklus I tindakan II dapat disimpulkan bahwa dari 8 anak, anak yang berada pada kategori belum berkembang (Belum Berkembang) berjumlah 1 anak, pada kategori mulai berkembang (MB) berjumlah 2 anak, pada kategori berkembang sesuai harapan (BSH) berjumlah 4 anak. Sementara itu, anak yang berada pada kategori berkembang sangat baik (BSB) berjumlah 1 anak.

Hasil pencapaian kemampuan sikap ilmiah anak pada akhir siklus I dapat dilihat dalam diagram batang berikut ini:

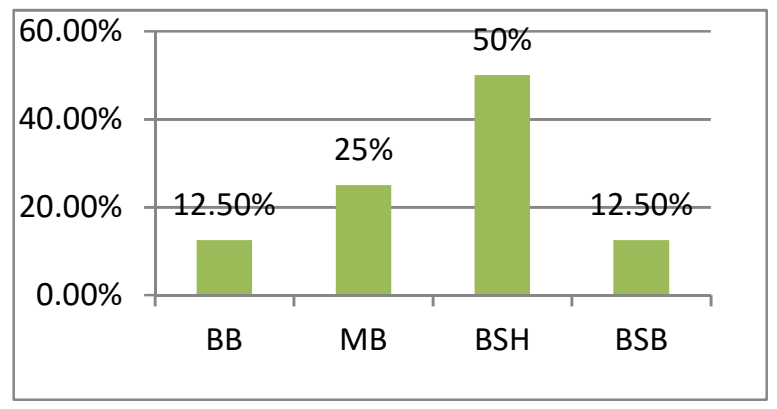

Diagram 1. Persentase kemampuan sikap ilmiah anak pada akhir siklus I

\section{Siklus II}

Hasil dari siklus II tindakan II dapat disimpulkan bahwa dari 8 anak, tidak ada anak yang berada pada kategori belum berkembang (Belum Berkembang) dan mulai berkembang (MB), anak yang berada pada kategori berkembang sesuai harapan (BSH) berjumlah 6 anak. Sementara itu, anak yang berada pada kategori berkembang sangat baik (BSB) berjumlah 2 anak. Jika digambarkan dalam bentuk diagram, hasilnya seperti berikut.

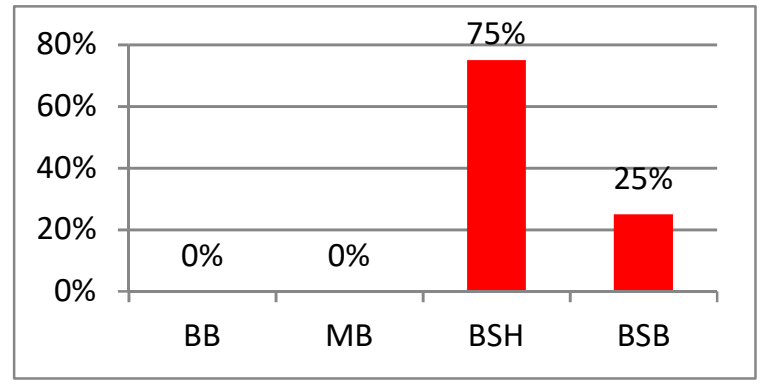

Diagram 2. Persentase kemampuan sikap ilmiah anak pada akhir siklus II

\section{Profil Kemampuan Sikap Ilmiah Anak Kelompok B1 RA Ar-Royyan Sebelum Penerapan Pembelajaran Sains dengan Metode Inkuiri}

Menurut wawancara dan observasi yang telah dilakukan pada tanggal 23 Maret 2016, metode yang digunakan untuk mengembangkan pembelajaran sains di RA Ar-Royyan ini adalah metode demonstrasi dan terkadang eksperimen. Saat pembelajaran sains ini dilaksanakan, seluruh anak, baik dari kelompok A, B1, dan B2 dikumpulkan dalam satu ruang dengan kegiatan yang sama.

Apabila dilihat dari pernyataan tersebut, dapat dikatakan bahwa pembelajaran sains di RA Ar-Royyan ini kurang optimal. Hal ini dikarenakan kegiatan yang diberikan antara kelompok A dan kelompok B sama, padahal sudah jelas indikator yang harus dicapai dari kedua 
kelompok ini berbeda. Apabila kegiatan pembela-jaran yang diberikan disesuaikan untuk anak kelompok $\mathrm{A}$, maka anak kelompok B akan merasa bosan dengan kegiatan karena terlalu mudah. Sebaliknya, apabila kegiatan pembelajaran yang diberikan disesuaikan untuk anak kelompok B, maka anak kelompok A akan merasa kesulitan dengan pembelajaran yang diberikan. Oleh karena itu, ada baiknya kegiatan sains yang diberikan untuk anak, harus dibedakan antara kelompok A dan kelompok B.

Selain itu, kegiatan yang guru lakukan saat pembelajaran sains ternyata lebih terlihat seperti pembelajaran seni rupa. Hal ini dikarenakan kegiatan hanya berkisar kepada kegiatan yang menggunakan pewarna, seperti cat, crayon, dsb, dan anak hanya mengikuti apa yang dilakukan guru tanpa guru menjelaskan apa maksud atau konsep sains yang ada dari kegiatan yang telah dilakukan. Guru di sini memiliki kecenderungan tidak nyaman atau percaya diri dengan pengetahuan mereka tentang sains sehingga kurang mampu menyampaikan konsep sains pada anak. Ini ternyata terjadi karena guru yang akan mengajar sains tidak mempersiapkan materi dan bahan yang akan diberikan pada anak sebelumnya. Guru di sini cenderung menunggu kepala sekolah untuk mengintruksikan apa yang akan dilakukan pada hari itu juga. Bahkan terkadang kegiatan sangat jauh berbeda dan tidak sesuai dengan tema yang digunakan.

Selanjutnya, pembelajaran sains dengan metode demonstrasi yang dilakukan di RA Ar-Royyan memang dikatakan oleh gurunya sendiri lebih menekankan kepada proses sainsnya saja. Padahal ruang lingkup pengembangan pembelajaran sains apabila ditinjau dari bidang pengembangan atau kemampuan yang harus dicapai oleh anak menurut Nugraha (2008, hlm. 94) harus mencakup 3 dimensi, yaitu meliputi kemampuan terkait dengan penguasaan produk sains, penguasaan proses sains, dan penguasaan sikap-sikap sains (sikap ilmiah).

Tujuan pengembangan pembelajaran sains yang terkait dengan dimensi produk adalah pendidikan sains diarahkan pada pengenalan dan penguasaan fakta, konsep, teori mapun aspek-aspek lain terkait dengan hal-hal yang ditemukan dalam bidang sains itu sendiri. Tujuan pengembangan pembelajaran sains yang terkait dengan dimensi proses adalah tujuan diarahkan pada penguasaan keterampilan-keterampilan yang diperlukan dalam menggali dan mengenal sains. Sementara tujuan pengembangan pembelajaran sains yang terkait dengan dimensi sikap dimaksudkan dalam pengembangan pembelajaran sains pada anak usia dini secara bertahap anak diarahkan pada suatu pembentukan pribadi atau karakter, sehingga anak telah ditanamkan benih-benih sikap yang sesuai dengan tuntutan dan kriteria sebagai seorang benar dalam memahami dan mendalami sains.

Menilik dari uraian di atas, dapat disimpulkan bahwa kemampuan sikap ilmiah anak yang rendah dikarenakan metode yang digunakan tidak sesuai untuk anak kelompok B1 RA Ar-Royyan, guru kurang dapat menyajikan materi pembelajaran sains untuk mengembangkan seluruh kemampuan sains pada diri anak, kurangnya persiapan dalam pelasanaan pembelajaran sains, serta kurang kondusifnya lingkungan belajar anak.

Oleh karena itu, langkah yang diambil peneliti dalam meningkatkan kemampuan sikap ilmiah anak kelompok B1 RA ArRoyyan yaitu dengan menyiapkan materi dan media pembelajaran sains secara konkrit dan menggunakan metode inkuiri yang 
menurut Haury (1994, hlm. 28) bahwa dengan menggunakan metode ini membuat pembelajaran sains lebih menyenangkan, baik itu bagi guru maupun anak, karena anak akan terjun langsung dalam memanipulasi objek untuk memperoleh pengetahuan.

Pelaksanaan Pembelajaran Sains dengan Metode Inkuiri Untuk Meningkatkan Kemampuan Sikap Ilmiah Anak
Kelompok B1 RA Ar-Royyan

Pelaksanaan penelitian ini sendiri dilakukan selama dua minggu, yang berlangsung pada tanggal 8 Maret sampai dengan 17 Maret 2016. Penelitian menempuh dua siklus dan setiap siklus terdapat dua tindakan yang diberikan. Selama penelitian ini, tema yang digunakan dalam penelitian adalah "Air, Udara, dan Api".

Dalam setiap tindakan, peneliti dan guru melakukan diskusi untuk merencanakan kegiatan yang akan dilaksanakan, seperti membuat RPPH (Rencana Pelaksanaan Pembelajaraan Harian) dan skenario pembelajaran, serta alat observasi yang akan digunakan. Kemudian melaksanakan tindakan sesuai dengan rencana yang telah dibuat, melakukan pengamatan dan refleksi terhadap kegiatan yang telah dilaksanakan untuk menentukan keberlanjutan siklus.

Pelaksanaan tindakan dalam setiap siklus menggunakan langkah-langkah metode inkuiri yang dikembangkan Haury (2002, hlm. 7) yang disebut the circle of inquiry yang memiliki empat tahap sehingga dalam pelaksanaan tindakan guru harus melaksanakan keempat tahapan ini yang terdiri dari wondering, collecting data, studying data, dan making connection.

Pelaksanaan siklus I tindakan I dilakukan dengan topik sifat-sifat air. Dalam pelaksanaannya, anak cukup antusias dalam melaksanakan kegiatan pembelajaran. Akan tetapi, guru kurang dapat melaksanakan tahapan inkuiri secara terstruktur. Hal ini dikarenakan guru yang seharusnya mengajar berhalangan hadir, sehingga guru pendamping yang melaksanakan kegiatan pembelajaran dengan metode inkuiri. Selain itu, kendala yang ditemukan adalah media warna yang digunakan untuk kegiatan menyepuh kurang bervariasi, seharusnya disediakan beberapa warna yang lain agar anak lebih antusias mengerjakan kegiatan ini.

Pada siklus I tindakan II, setelah dilakukannya pelatihan kepada dua guru atas persetujuan peneliti dan guru kelas, tahapan inkuiri yang dilakukan oleh guru berjalan dengan lancar. Antusisme anak dalam pembelajaran semakin meningkat dimana anak dengan sigap dapat merespon apa yang guru tanyakan atau minta lakukan. Akan tetapi pada saat menjelaskan kegiatan yang harus dikerjakan anak, guru kurang jelas menjelaskannya. Untuk media, terdapat media yang kurang berupa baskom, tetapi dapat digantikan dengan menggunakan botol. Karena dalam siklus I tindakan II ini sikap ilmiah yang kurang muncul adalah sikap berpikiran terbuka, maka guru dan peneliti telah mendiskusikan untuk memberikan kegiatan dimana anak dapat berinteraksi secara intens dengan temannya melalui kegiatan berkelompok.

Kemampuan sikap ilmiah anak pada siklus II tindakan I mengalami perubahan. Setelah melakukan kegiatan berkelompok, sikap kerjasama anak muncul, guru semakin lancar dalam melaksanakan tahap inkuiri. yang menjadi kendala adalah media yang kurang sesuai untuk anak, yaitu botol terlalu besar, akan tetapi masih dapat ditangani dengan pemberian solatip pada ujung botol. 
Secara keseluruhan kemampuan sikap ilmiah anak Kelompok B1 RA Ar-Royyan mengalami perubahan yang positif. Sudah tidak ada kendala yang dihadapi pada siklus II tindakan II ini. Setelah peneliti melakukan diskusi dengan guru kelas, diputuskan siklus dihentikan pada siklus II tindakan II. Hal ini dikarenakan sesuai dengan indikator keberhasilan yang telah ditetapkan oleh peneliti. Indikator keberhasilan yang ditetapkan dalam penelitian ini dilihat berdasarkan dua aspek, yaitu aspek proses dan aspek hasil. Aspek proses telah terlihat dimana prosedur pelaksanaan tindakan yang telah sesuai, keaktifan anak dalam melaksanakan kegiatan pembelajaran sains dengan metode inkuir, serta kepuasaan anak terhadap kegiatan pembelajaran yang diikuti. Sementara itu, indikator keberhasilan pada aspek hasil mengacu kepada sejauh mana peningkatan atau penurunan pada kategori yang telah ditetapkan dimana penelitian dihentikan apabila anak yang berada pada kategori belum berkembang (BB) mengalami penurunan sampai dengan $0 \%$ dan terjadi peningkatan pada kategori berkembang sesuai dengan harapan (BSH) sampai dengan 75\%. Akan lebih baik, apabila peningkatan pada kategori berkembang sangat baik (BSH) memiliki persentase sama banyaknya dengan kategori berkembang sesuai harapan $(\mathrm{BSH})$, akan tetapi karena peneliti terkendala waktu dimana penelitian dilakukan pada akhir semester dua ketika sekolah sedang bersiapsiap untuk pembagian rapot, maka penelitian ini tidak dapat dilanjutkan lagi.

Akan tetapi, secara keseluruhan pada siklus II tindakan II, kemampuan sikap ilmiah anak kelompok B1 RA Ar-Royyan sudah meningkat. Perolehan rata-rata kemampuan sikap ilmiah anak meningkat dan berada pada kategori berkembang sesuai harapan yang menjadi indikator keberhasilan penelitian ini. Anak memiliki rasa ingin tahu yang tinggi, memiliki pikiran yang terbuka, memiliki sikap tekun saat mengerjakan kegiatan, dapat bekerja sama dan peka terhadap lingkungan.

Peningkatan Kemampuan Sikap Ilmiah Anak Kelompok B1 RA Ar-Royyan Setelah Penerapan Pembelajaran Sains dengan Metode Inkuiri

Berdasarkan pengamatan pada observasi awal, rata-rata kemampuan sikap ilmiah anak Kelompok B1 RA Ar-Royyan masih berada pada kategori belum berkembang. Akan tetapi, setelah diterapkannya pembelajaran sains dengan metode inkuiri, secara bertahap kemampuan sikap ilmiah anak mengalami peningkatan. Sehingga dapat disimpulkan bahwa setelah diterapkannya pembelajaran sains dengan metode inkuiri pada anak Kelompok B1, kemampuan sikap ilmiah anak mengalami peningkatan yang signifikan. Hal ini dapat dilihat bahwa dari 8 anak, yang termasuk pada kategori belum berkembang (BB) berjumlah 6 anak dengan persentase 75\% menurun menjadi $12,5 \%$ dengan jumlah 1 anak pada akhir siklus I dan kembali menurun sampai dengan $0 \%$ tanpa ada anak yang berada pada kategori ini pada akhir siklus II. Selanjutnya pada kategori mulai berkembang (MB), awal observasi diperoleh persentase $12,5 \%$ dengan jumlah 1 anak menjadi $25 \%$ dengan jumlah 2 anak pada akhir siklus I dan menjadi $0 \%$ pada akhir siklus II. Untuk kategori berkembang sesuai harapan (BSH), persentase pada awal observasi sebesar $12,5 \%$ dengan jumlah 1 anak meningkat menjadi $50 \%$ pada akhir siklus I dengan jumlah 4 anak dan kembali meningkat menjadi $75 \%$ pada akhir siklus II dengan jumlah 6 anak. Sementara itu, pada kategori berkembang sangat baik (BSB), awal observasi belum ada anak yang berada 
pada kategori ini dengan persentase $0 \%$ meningkat menjadi $12,5 \%$ dengan jumlah 1 anak pada akhir siklus I dan kembali meningkat menjadi $25 \%$ dengan jumlah 2 anak pada akhir siklus II.

Dengan menggunakan metode inkuiri ini kegiatan pembelajaran yang dilakukan oleh guru lebih terstruktur. Bukan hanya anak yang mengalami kepuasaan saat belajar, guru pun mengalami kepuasaan saat mampu mengarahkan tujuan pembelajaran sains yang mengacu pada 3 dimensi, yaitu dimensi produk, proses, dan sikap. Jelas bahwa pembelajaran dengan menggunakan metode inkuiri mengantarkan anak pada tujuan instruksional tingkat tinggi. Pencarian pengetahuan secara bersama-sama antara guru dan anak akan lebih bermakna daripada hanya anak menerima pengajaran langsung dari guru.

Haury (2002, hlm. 71) menyatakan bahwa "...inquiry-related teaching effective in fostering scientific literacy and understanding of science processes, vocabulary knowledge and conceptual understanding, critical thinking, positive attitudes toward science, higher achievement on tests of procedural knowledge, and construction of logicomathematical knowledge".

Metode inkuiri terbukti meningkatkan prestasi belajar dan sikap anak terhadap sains dan matematika serta membantu perkembangan antara lain scientific literacy dan pemahaman proses-proses ilmiah, pengetahuan vocabulary dan pemahaman konsep, berpikir kritis, dan bersikap positif. Dengan kata lain metode inkuiri ini bukan hanya meningkatkan pemahaman terhadap konsep-konsep dalam sains saja, akan tetapi juga membentuk sikap keilmiahan dalam diri anak.

\section{SIMPULAN}

Berdasarkan hasil penelitian yang dilakukan di RA Ar-Royyan, maka dapat diperoleh kesimpulan sebagai berikut:

1. Kemampuan sikap ilmiah anak kelompok B1 RA Ar-Royyan Tahun Ajaran 2015-2016 sebelum penerapan pembelajaran sains dengan metode inkuiri rata-rata masih berada pada kategori belum berkembang. Hal ini dikarenakan metode pembelajaran sains yang digunakan yaitu metode demonstrasi tidak dapat mengembangkan seluruh kemampuan sains terutama sikap ilmiah pada diri anak, guru kurang dapat menyajikan materi pembelajaran sains untuk mengembangkan seluruh kemampuan sains pada diri anak, kurangnya persiapan dalam pelasanaan pembelajaran sains, serta kurang kondusifnya lingkungan belajar anak.

2. Penelitian dilaksanakan dalam dua siklus dan dua tindakan pada setiap siklusnya. Tema yang digunakan adalah "Air, Udara, dan Api". Peneliti dan guru melakukan diskusi untuk merencanakan kegiatan yang akan dilaksanakan, seperti membuat RPPH dan skenario pembelajaran, serta alat observasi yang akan digunakan. Kemudian melaksanakan tindakan, melakukan pengamatan dan refleksi. Pelaksanaan siklus I tindakan I terkendala oleh guru yang belum terlalu mengenal metode inkuiri sehingga dilakukan pelatihan atau simulasi untuk menangani kendala tersebut. Kendala secara umum yang sering ditemui adalah ketidaksesuaian media. Kendala ini muncul mulai dari siklus I tindakan I sampai dengan siklus II tindakan I. Akan tetapi kendala ini dapat diatasi sesuai dengan apa yang ditemukan dilapangan. Pada akhir siklus II tidak ada lagi kendala yang dihadapi, 
sehingga siklus dihentikan kaena telah mencapai indikator keberhasilan yang telah ditetapkan.

3. Kemampuan sikap ilmiah anak setelah penerapan pembelajaran sains dengan metode inkuiri menunjukkan perubahan ke arah yang positif. Hal ini ditunjukkan dengan hasil observasi yang mengalami peningkatan pada setiap siklusnya. Dengan menggunakan metode inkuiri ini kegiatan pembelajaran yang dilakukan oleh guru lebih terstruktur. Bukan hanya anak yang mengalami kepuasaan saat belajar, guru pun mengalami kepuasaan saat mampu mengarahkan tujuan pembelajaran sains yang mengacu pada 3 dimensi, yaitu dimensi produk, proses, dan sikap. Jelas bahwa pembelajaran dengan menggunakan metode inkuiri mengantarkan anak pada tujuan instruksional tingkat tinggi. Pencarian pengetahuan secara bersama-sama antara guru dan anak akan lebih bermakna daripada hanya anak menerima pengajaran langsung dari guru.

\section{DAFTAR PUSTAKA}

Arikunto, S. (2010). Prosedur Penelitian: Suatu Pendekatan Praktik. (Edisi Revisi). Jakarta: Rineka Cipta.

Bundu, P. (2006). Model Keterampilan Proses dan Sikap Ilmiah dalam Pembelajaran Sains SD. Jakarta: Depdiknas.

Haury, D. L. \& Rillero P. (1994). Perspectives of Hands-On Science Teaching. Columbus, OH: ERIC Clearinghouse for Science, Mathematics, and Environmental Education.

Moeslichatoen, (2004). Metode Pengajaran di Taman Kanak-kanak. Jakarta: PT Rineka Cipta.

Nugraha, A. (2008). Pengembangan Pembelajaran Sains pada Anak Usia Dini. Jakarta: JILSI Foundation.

Suprapto, J. (2002). Statistik Teori dan Aplikasi. (Edisi Enam). Jakarta: Erlangga.
Wiyani \& Barnawi. (2012). Format PAUD (Pendidikan Anak Usia Dini). Yogyakarta: Ar-Ruzz Media. 